\title{
Pelleting pruning residues of mandarin for bio-energy
}

\author{
Biyoyakıt için mandalina budama atıklarının peletlenmesi
}

\author{
Metin DAĞTEKIN ${ }^{1}$ iD, Gürkan A. K. GÜRDiL ${ }^{2}$ \\ ${ }^{1}$ Çukurova University, Ceyhan Vocational School, Adana, Turkey. \\ ${ }^{2}$ Ondokuz Mayıs University, Faculty of Agriculture,Department of Agricultural Machines and Technologies Engineering, Samsun, \\ Turkey.
}

MAKALE BILGISI / ARTICLE INFO

Makale tarihçesi / Article history:

DOI: $\underline{10.37908 / m k u t b d .785095}$

Geliş tarihi /Received:25.08.2020

Kabul tarihi/Accepted:14.10.2020

\section{Keywords:}

Biofuel, mandarin, pellet, branch, residue.

\footnotetext{
Corresponding author: Metin DAĞTEKIN

$\bowtie:$ mmdagtekin@gmail.com
}

\section{ÖZET / A BSTRACT}

Atıf / Citation: Dağtekin M, Gürdil G. A. K. (2021) Pelleting Pruning Residues of Mandarin for Bio-Energy. MKU. Tar. Bil. Derg. 26(1) : 75-81. DOI: $10.37908 / m k u t b d .785095$

\section{INTRODUCTION}

As the population increases day by day people seeks for new energy sources and renewable energy sources in recent days become popular since they are environmental friendly and sustainable. Biomass is a good choice for alternative energy (Karaca, 2019). Biomass can be both plant and animal based feedstock. The potential of plant based biomass resources is high but, most of these sources are idle and unused. They are not used for any purposes unfortunately. Evaluation of pruning residues from fruit orchards as a biofuel source is a good solution for efficient use of residues.
Mandarin is a popular fruit especially in the Mediterranean region of Turkey. Approximately, 17.2\% of the world citrus production is realized by the countries in the Mediterranean Region. World citrus production increased about $18 \%$ in the world in last decade but, this increase was still higher $30 \%$ in Turkey (Uysan ve Polatöz, 2020). The largest production in the world after orange among the total citrus production was in mandarin. Total mandarin production in the world was 30.4 million tons. China ranks first in production with 16.2 million tons, followed by Spain with 2.4 million tons and Morocco with 1.2 million tons, respectively. Turkey ranked 4th in the world with 1.0 million tons of production. But, 
among the Mediterranean countries, Turkey ranked 2nd after Spain (Anonymous, 2017). Mandarin production in Turkey is recorded as 1650 tons, 549.9 tons of it is produced in Adana and the remaining in Mersin. In other words, approximately $48 \%$ of mandarin production in Turkey realized in Adana and Mersin (Anonymous, 2018). The most common procedure for maintaining the mandarin orchards is pruning. Pruning improves the strength and productivity of trees. It's also a good way of fighting against diseases. But, it generally generates residue problem. Although there is a big biomass potential from mandarin orchards unfortunately, most of these potential is just left on the fields or on the gardens for natural decomposition or just burned randomly near the garden (Figure 1).

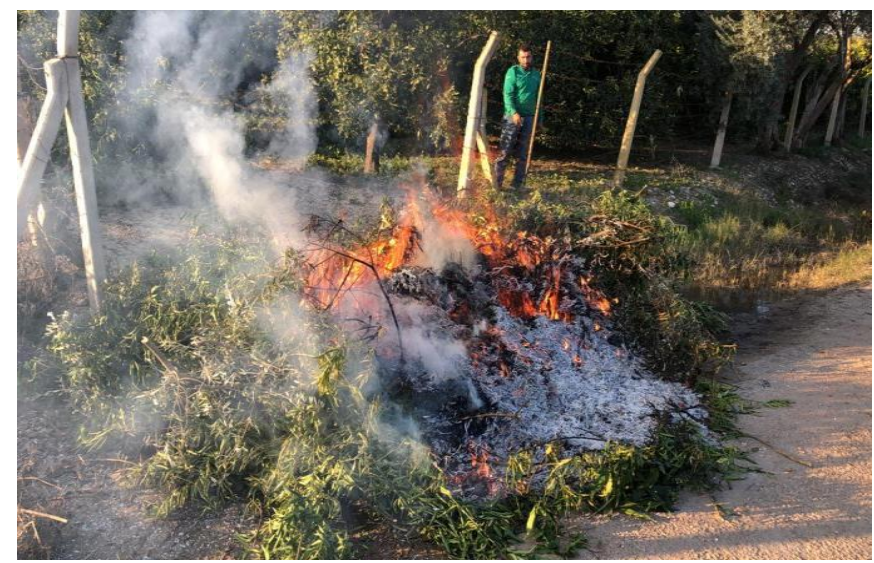

Figure 1. Random burning of mandarin pruning residues at orchard edges Şekil 1. Mandalina budama atıklarının bahçe kenarlarında rastgele yakılması

A good solution for utilizing this idle potential could be converting them into biomass in the form of pellets or briquettes. Pelleting is shaping the ground material under pressure to smaller sizes (Öztürk, 2012). Pellets can be produced from sawdust, wood chips, tree barks, agricultural products, straw, hazelnut shell, almond shell, walnut shell and even from waste papers, as well. The density of material is increased and the transportation and storing costs are decreased by pelleting process and also, homogeneity is provided (Werther et al., 2000; Mani et al., 2003; Holm et al., 2006; Nilsson et al., 2011; Theerarattananoon et al.,
2011). Pelleted biomass is low and uniform in moisture content (Fasina and Sokhansanj, 1996). As a general rule in fuels, the lower moisture contents the higher heating capacities. Thus, pellets can be a good biofuel in this sense.

The aim of this study is to utilize mandarin orchard pruning residues as solid biofuel in the form of pellets. For this purpose, the pruning residues of mandarin branches were first collected and chopped into smaller pieces (Figure 2). Then, some physical-mechanical and thermal properties of produced fuel pellets were analyzed with regards to particular EU standards.

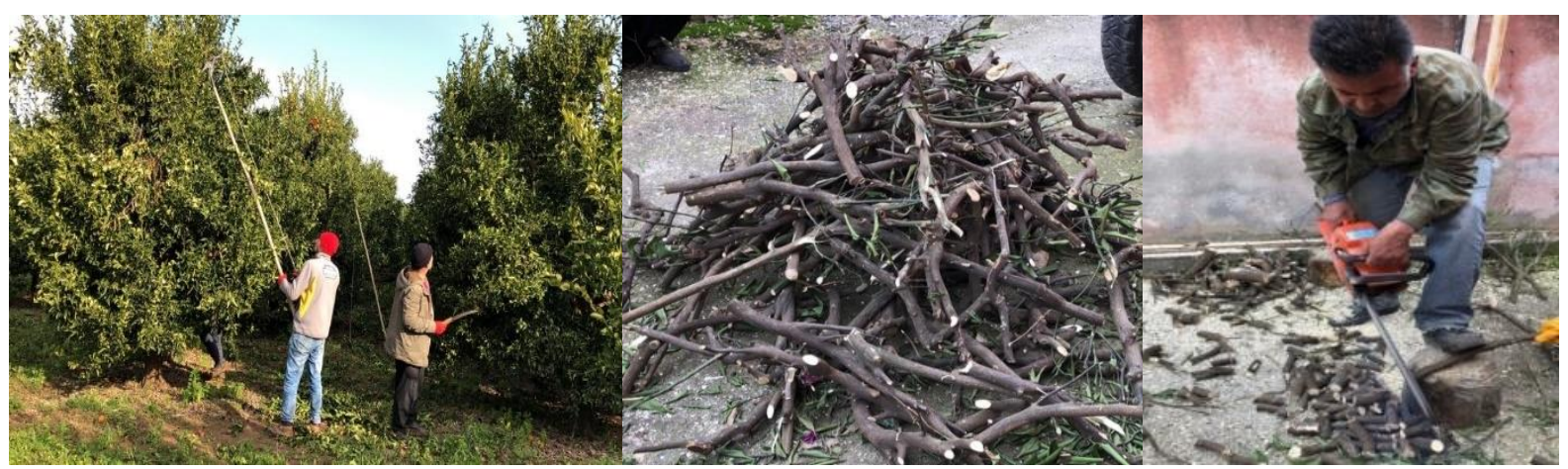

Figure 2. Pruning, collecting and chopping of mandarin pruning residues Şekil 2. Mandalina budama artıklarının budanması, toplanması ve doğranması 


\section{MATERIALS and METHODS}

The study is carried out in labs and workshop of Agricultural Machines and Technologies Engineering Department of Samsun Ondokuz Mayıs University with collaboration of Çukurova University in Adana in Turkey, pruning residues of mandarin tree (just the branches itself without the leaves etc.) were provided from the orchards in Tarsus district of Mersin province. Up to date European standards were taken as a reference for this research. The pre-fragmented and chopped material was sun dried under natural conditions until their moisture content was reduced to M10 (8-10 \%) as mentioned in EU standards for pellets (EN 14961-2, 2010; EN ISO 17225-6, 2015). Then they were ground by a hammer mill into three different particle sizes (PS) by using three different sieves having 4, 6 and $8 \mathrm{~mm}$ hole diameters The motor power of the hammer mill operating with three-phase electrical energy is $22 \mathrm{~kW}$, and its grinding capacity is 2.5 tons $\mathrm{h}^{-1}$. The mill has 24 hammers and 2,4,6,8 $\mathrm{mm}$ circular sized sieves (Figure 3 ).

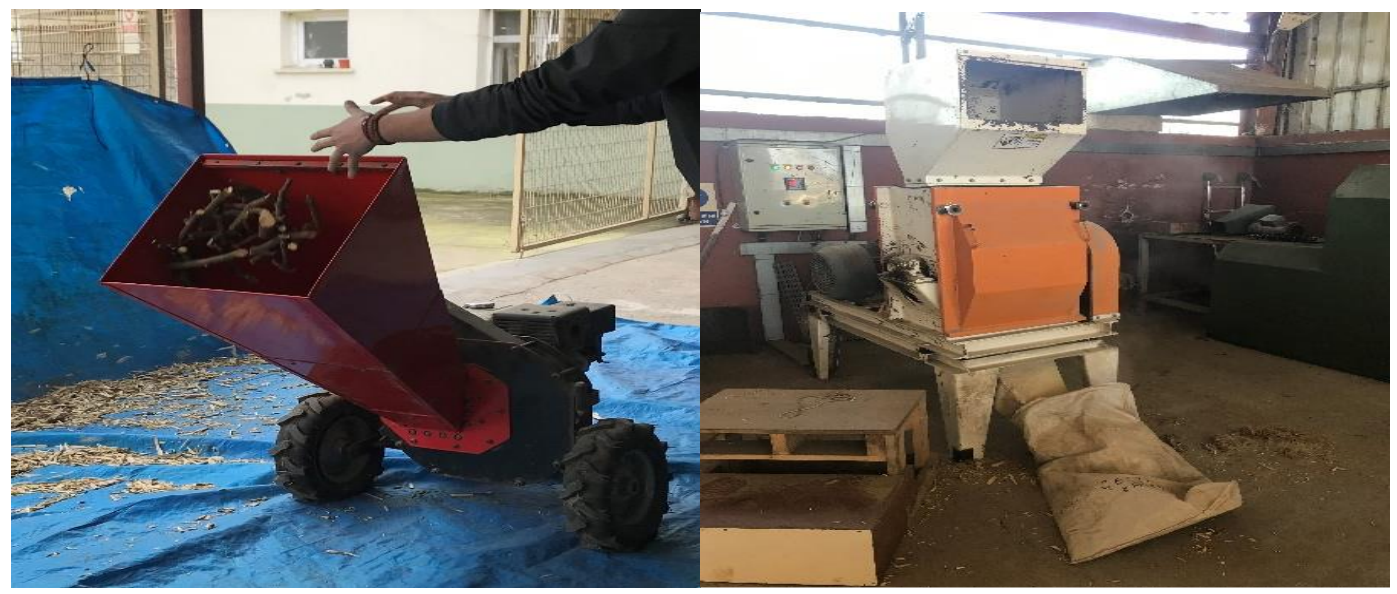

Figure 3. Chopping and grinding of mandarin pruning residues

Şekil 3. Mandalina budama atıklarının doğranması ve ögü̈tülmesi

Ground particles were pelleted using a pelleting machine and pellets from varying particle sizes were produced. Pelleting machine has been used, having $3 \mathrm{~kW}$ motor power and with capacity of 50-100 $\mathrm{kg} \mathrm{h}^{-1}$ depending on the material type and the pellet size can be adjusted between 10-40 mm. Pelletizing machine consists of material storage, circular row perforated flat die, compression rollers, pellet size adjustment unit and electrical control panel. The pellet mold used is flat mold with circular rows of holes (Figure 4). Particle density of pellets were calculated according to standard (EN 15150, 2011). Bulk densities for pellets were calculated as defined in the particular standards (EN 15103, 2009). In order to determine the bulk density of the pellets, the container with a volume of $50 \mathrm{~L}$ is fully filled to form a cone from approximately $200-300 \mathrm{~mm}$ height. The container is then left free on the hard floor from a height of approximately $150 \mathrm{~mm} 3$ times.

The excess material at the top of the container is then moved out of the container with a flat and long wooden material and larger gaps in the upper portion of the container are filled. The pellet bulk density was calculated as $\mathrm{kg} \mathrm{m}^{-3}$ with the help of the following equation.

$$
\begin{aligned}
& V_{u}=\frac{\pi \times D^{2} \times L}{4} \\
& P_{u}=\frac{m_{u}}{V_{u}}
\end{aligned}
$$

Where; $V_{u}$ : Volume of the container $\left(\mathrm{m}^{3}\right), \mathrm{P}_{\mathrm{u}}$ : The pellet bulk density $\left(\mathrm{kg} \cdot \mathrm{m}^{-3}\right), \mathrm{m}_{\mathrm{u}}$ : Pellet mass $(\mathrm{kg})$

Mechanical durability of the pellets was tested according to standard (EN 15210-1, 2009). In the measurement, a resistance test device with a motor power of $0.37 \mathrm{~kW}$, a motor reducer speed of $50 \mathrm{rpm}$, a cage size of $300 \times 300 \times 125 \mathrm{~mm}$ where the pellets will be placed, and a plate (baffle) with a length of $50 \mathrm{~mm}$ in width and 230 $\mathrm{mm}$ in length was used, which was placed cross symmetrically in the inner center of the cage. Pellet firmness parameter is important during transportation and storage of pellets. The firmness values were determined with a special load testing device (Figure 5). Thermal parameters, flue gas emissions and ash rate measurements were made at the Black Sea Agricultural Research Institute. In determining the flue gas emission values, pellets were filled into the fuel tank of the pellet stove. The flue gas emission values $\left(\mathrm{O}_{2}(\%), \mathrm{CO}(\mathrm{ppm})\right.$, $\left.\mathrm{CO}_{2}(\%), \mathrm{NO}(\mathrm{ppm}), \mathrm{NOx}(\mathrm{ppm}), \mathrm{SO}_{2}(\mathrm{ppm})\right)$, which occur 
when complete combustion occurs, were measured with a gas analyzer at 3-minute intervals (EN ISO 17225-6, 2015).

In determining the ash content of the pellets, porcelain crucibles were kept in an ash furnace at $575 \pm 25^{\circ} \mathrm{C}$ for a minimum of 4 hours, taken into a desiccator and weighed by cooling. Then, the cooled crucibles were placed in the ash furnace again and waited for constant weight. When the porcelain crucibles reached a constant weight, 0.5-2 g sample (dried in the oven) was weighed and placed in the oven. The oven temperature has been raised according to a certain increment program (EN $14775,2009)$. The temperature increase program was made as follows;

The oven temperature was raised from room temperature to $105^{\circ} \mathrm{C}$ and kept at this temperature for 12 minutes.

The temperature was raised to $250{ }^{\circ} \mathrm{C}$ with an increase of $10{ }^{\circ} \mathrm{C} \mathrm{min}^{-1}$ and kept at this temperature for 30 minutes.

The temperature was increased to $575^{\circ} \mathrm{C}$ with an increase of $20^{\circ} \mathrm{C} \mathrm{min}-1$ and kept at this temperature for 180 minutes.

In measuring the thermal parameters, the pellets were kept at $105^{\circ} \mathrm{C}$ for 24 hours before the measurement and the moisture inside was removed. Samples dried at a mass of $0.5 \mathrm{~g}$ were burned in an oxygen environment in a calorimeter bomb under standard conditions, and the thermal parameters were determined according to the increase in the temperature of the water in the calorimeter container and the average actual heat capacity of the system. The heat of combustion; It is calculated by monitoring the temperature before, during and after the combustion process and applying thermochemical and heat exchange corrections to them (EN 14918, 2009).

Data analysis was performed using the IBM SPSS Statistics 21 software. The normality analysis was performed with the Kolmogorov-Smirnov single sample test and the variance homogeneity was assessed by the Levene test and the variances were homogeneous $(P>0.05)$, with normal distribution of the data.

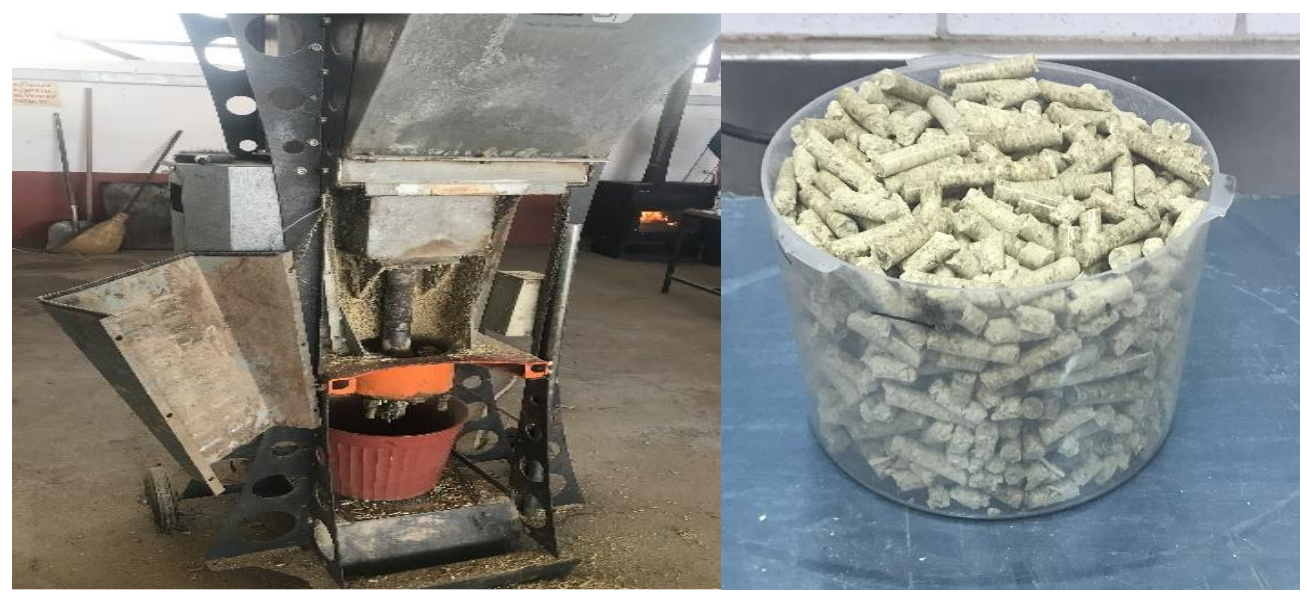

Figure 4. Pelleting machine and produced pellets

Şekil 4. Pelet makinası ve üretilen peletler

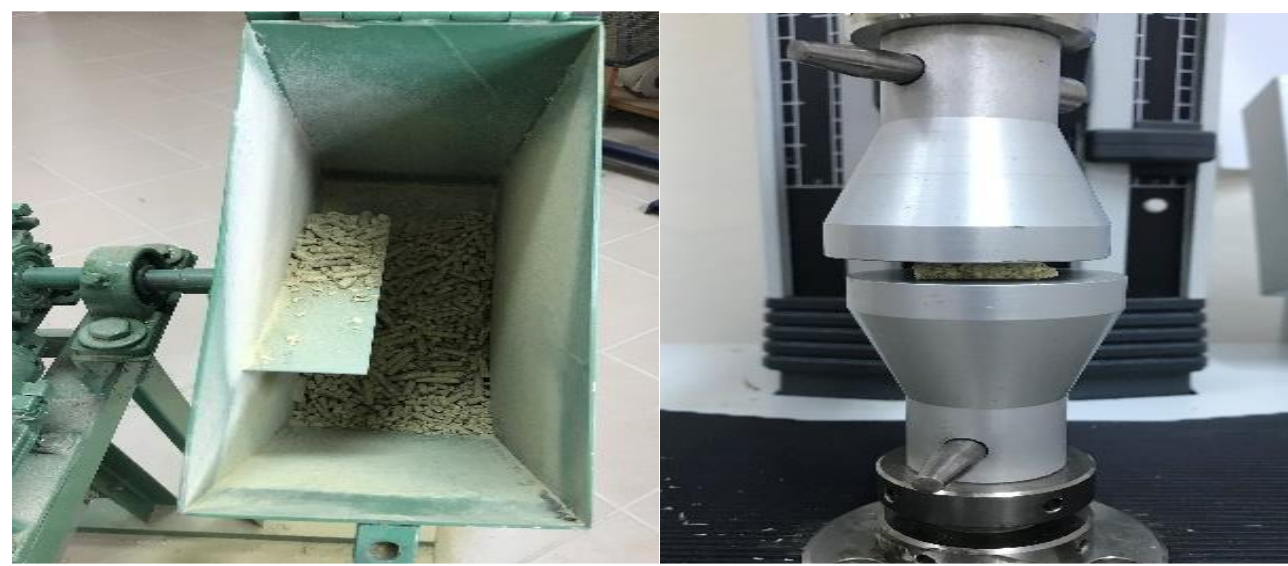

Figure 5. Mechanical durability and firmness tests

Şekil 5. Mekanik dayanıklılık ve sertlik testleri 


\section{RESULTS and DISCUSSION}

\section{Physical-mechanical parameters}

Bulk and particle densities of the produced pellets were given in Table 1, below.

As seen from the table the effect of PS on pellet particle and bulk densities were found statistically significant. The results for pellet bulk densities were more than the values found for the tomato residues $\left(200 \mathrm{~kg} \mathrm{~m}^{-3}\right)$ at M10 (Celma et al., 2012). This can be because of the structure of the material since the orange pruning residues have woody and harder structure (Holm et al., 2006). This was also proved by the estimation proposed in (EN 15103, 2009), too. That herbaceous pellets are expected to have lower bulk densities than sawdust. The effect of pellet (PS) on pellet mechanical durability (MD) and firmness were found statistically significant (Table 2).

The pellets with smaller PS values had the lower MD values always and it was the same for firmness values, too. The MD of pellets were not in the range given in EU standards (EN 15210-1, 2009). But, some researchers indicated that the pellet quality is high when the MD value is $80 \%$ and higher, medium when $M D$ is ranging from 70 to $80 \%$ and low quality when MD $\leq 70 \%$ (Tabil and Sokhansanj, 1996; 1997). So, the MD values of produced pellets are said to be acceptable. Firmness and MD values had parallel fluctuations as the PS values of pellets increased.

Table 1. Pellet bulk densities

Çizelge 1. Pelet yığın yoğunlukları

\begin{tabular}{ccc}
\hline $\begin{array}{c}\text { Particle size } \\
(\mathrm{mm})\end{array}$ & $\begin{array}{c}\text { Pellet bulk density* } \\
\left(\mathrm{kg} \mathrm{m}^{-3}\right)\end{array}$ & $\begin{array}{c}\text { Pellet density* } \\
\left(\mathrm{kg} \mathrm{m}^{-3}\right)\end{array}$ \\
\hline 4 & $480.20 \pm 3.25 \mathrm{a}$ & $1270.10 \pm 5.28 \mathrm{~b}$ \\
6 & $507.12 \pm 3.25 \mathrm{a}$ & $1230.17 \pm 2.85 \mathrm{a}$ \\
8 & $474.31 \pm 1.83 \mathrm{c}$ & $1260.83 \pm 1.03 \mathrm{c}$ \\
Sig. & $<0.001$ & $<0.001$ \\
\hline
\end{tabular}

*The difference between the values carrying the same letter is insignificant

Table 2. Mechanical durability and firmness of pellets*

Çizelge 2. Peletlerin mekanik dayanıklıı̆̆ ve sertliği

\begin{tabular}{ccc}
\hline PS $(\mathrm{mm})$ & MD $(\%)$ & Firmness (N) \\
\hline 4 & $79.46 \pm 0.01 \mathrm{a}$ & $2039.34 \pm 22.80 \mathrm{~d}$ \\
6 & $86.04 \pm 0.07 \mathrm{~b}$ & $2266.60 \pm 18.74 \mathrm{~b}$ \\
8 & $92.14 \pm 0.06 \mathrm{c}$ & $2807.40 \pm 10.70 \mathrm{c}$ \\
Sig. & $<0.001$ & $<0.001$ \\
\hline
\end{tabular}

*The difference between the values carrying the same letter is insignificant

\section{Thermal parameters}

Ash content of the pellets produced from 4, 6 and $8 \mathrm{~mm}$ PS were found as $5.63 \%, 5.65 \%$ and $5.65 \%$, respectively. This is in line with the reference value $(\mathrm{A} 10 \leq 10 \%)$ given in standard (EN ISO 17225-6, 2015). Lower heating value of pellets was found as $18.66 \mathrm{MJ} \mathrm{kg}^{-1}$. That is also in line with the value $\left(014.5 \geq 14.5 \mathrm{MJ} \mathrm{kg}^{-1}\right)$ indicated in the above mentioned standard. The results showed that the heating value of pellets produced from mandarin tree pruning residues are higher than the wood $\left(17.57 \mathrm{MJ} \mathrm{kg}^{-}\right.$ $\left.{ }^{1}\right)$ (Anonymous, 2020). That could be considered as a very good result especially, when the big waste potential is concerned. The flue gases of the pellets (PS: $8 \mathrm{~mm}$ ) are presented in Table 3, below. The pellets made from PS: $8 \mathrm{~mm}$ had the highest MD and Firmness values. The tougher material the slower burning rate and burning quality. That's the reason why results of PS: $8 \mathrm{~mm}$ were given only in Table 3, below.

Table 3. Flue gas emissions of pellets (PS: $8 \mathrm{~mm}$ ) Çizelge 3. Peletlerin baca gazı emisyonları $(8 \mathrm{~mm}$ parçacık boyutlu)

\begin{tabular}{ccccc}
\hline $\begin{array}{c}\mathrm{NOx} \\
(\mathrm{ppm})\end{array}$ & $\mathrm{CO}_{2}(\%)$ & $\mathrm{O}_{2}(\%)$ & $\mathrm{CO}(\mathrm{ppm})$ & $\mathrm{NO}(\mathrm{ppm})$ \\
\hline 112.67 & 5.5 & 15.40 & 1007.33 & 1073.30
\end{tabular}

The measured emission value for $\mathrm{CO}_{2}$ was in the limits $(20.5 \%)$ given in Regulations for Air Pollution Control (IKHKKY, 2014). 


\section{CONCLUSIONS}

Utilization of mandarin orchard pruning residues as source of solid biofuel in the form of pellets were investigated in this study. Pellets were produced with 4, 6 and $8 \mathrm{~mm}$ PS at M10 moisture content. Some physicalmechanical and thermal properties of fuel pellets were determined and analyzed. All the tests were done according to the recent EU standards. The highest pellet bulk density was obtained as $507.12 \mathrm{~kg} \mathrm{~m}^{-3}$ from the pellets produced with PS: $6 \mathrm{~mm}$. But, the highest pellet density was obtained at PS: $4 \mathrm{~mm}$ pellets as 1270.10 $\mathrm{kg} \cdot \mathrm{m}^{-3}$. The pellets made from $8 \mathrm{~mm}$ particle sized ground material had the highest MD and firmness values as $92.14 \%$ and $2807.40 \mathrm{~N}$, respectively. $\mathrm{CO}_{2}$ emission of pellets were within the defined limits regarding to IKHKKY regulations as from the environmental point of view. Energy is the biggest problem of today's world. Biomass energy obtained from unused agricultural wastes and residues is a good choice since it's sustainable. They are everywhere and easy to handle and utilize. We believe that the results of this study will have a positive contribution to this scientific area and further researches must be done in order to broaden the biomass kind.

\section{ÖZET}

Amaç: Bu çalışmanın amacı, mandalina bahçesi budama artıklarının pelet şeklinde biyoyakıt potansiyelini değerlendirmektir.

Yöntem ve Bulgular: Peletler, üç farklı parçacık boyutundan $(4,6$ ve $8 \mathrm{~mm})$ ve $M 10$ (\% 8 - 10) nem içeriğinde üretilmiştir. Peletlerin bazı ısısal ve fizikomekanik özellikleri güncel $A B$ (Avrupa Birliği) standartlarına göre incelenmiş ve kontrol edilmiştir. Pelet yığın yoğunlukları $474 \mathrm{~kg} \mathrm{~m}^{-3}$ ile $507 \mathrm{~kg} \mathrm{~m}^{-3}$ arasında değişirken, pelet yoğunlukları $1230 \mathrm{~kg} \mathrm{~m}^{-3}$ ve $1270 \mathrm{~kg} \mathrm{~m}^{-3}$ arasında gerçekleşmiştir. Mekanik dayanıklılık (MD) değerleri \%79.46 ile \%92.14 arasında, sertlik değerleri $2039.34 \mathrm{~N}$ ile $2807.40 \mathrm{~N}$ arasında değişmiştir. Kül içeriği \%5.64 ve peletlerin alt ısıl değeri $18.66 \mathrm{MJ} \mathrm{kg}^{-1}$ olarak tespit edilmiştir.

Genel Yorum: Üretilen tüm peletlerin ölçülen fizikomekanik özellikleri katı biyoyakıt standartları açısından uygun bulunmuştur. Ayrıca, baca gazı emisyonları, çevre koruma için ısıtma yönetmeliklerinde belirtilen sınırlarlar arasında çıkmıştır. Peletlerin ısıl değerleri katı yakıt olarak kabul edilebilir düzeydedir.

Çalışmanın Önemi ve Etkisi: Elde edilen sonuçlar, mandalina ağaçlarının budama artıklarının biyoyakıt kaynağı için hem teknik hem de çevresel açılardan uygun olduğunu göstermiştir.

Anahtar Kelimeler: Biyoyakıt, mandalina, pelet, dal, atık.

\section{CONFLICT OF INTEREST}

The authors declare no conflict of interest for this study.

\section{AUTHOR'S CONTRIBUTIONS}

The contribution of the authors is equal.

\section{REFERENCES}

Anonymous (2017) Food and Agriculture Organization of the United Nations. http://www.fao.org/faostat/en/\#home, accessed on May 29, 2017.

Anonymous

https://biruni.tuik.gov.tr/bitkiselapp/bitkisel.zul

Statistics for plant production. Turkish Statistical Institute, Ankara, accessed on May 17, 2020.

Anonymous (2020) The engineering toolbox. URL: https://www.engineeringtoolbox.com/wood-

combustion-heat-d 372.html. Accession date: 06.10.2020

Celma AR, Cuadros F, Rodriguez FL (2012) Characterization of pellets from industrial tomato residues. Food and Bioproducts Processing 90(4): 700-706.

EN 15103 (2009) Solid biofuels - Determination of bulk density. European Committee for Standardization: Management Centre, Avenue Marnix 17, B-1000 Brussels

EN 15210-1 (2009) Solid biofuels - Determination of mechanical durability of pellets and briquettes Part 1: Pellets. European Committee for Standardization: Management Centre, Avenue Marnix 17, B-1000 Brussels

EN 14775 (2009) Solid biofuels - De-termination of ash content. European Committee for Standardization: Manage-ment Centre, Avenue Marnix 17, B-1000 Brussels

EN 14918 (2009) Solid biofuels - De-termination of calorific value. European Committee for Standardization: Management Centre, Avenue Marnix 17, B-1000 Brussels.

EN 14961-2 (2010) Solid biofuels- Fuel specifications and classes- Part 2: Wood pellets for non-industrial use. European Committee for Standardization: Management Centre, Avenue Marnix 17, B-1000 Brussels.

EN 15150 (2011) Solid biofuels - Determination of particle density. European Committee for 
Standardization: Management Centre, Avenue Marnix 17, B-1000 Brussels.

EN ISO 17225-6 (2015) Solid biofuels -- Fuel specifications and classes -- Part 6: Graded nonwoody pellets. European Committee for Standardization: Management Centre, Avenue Marnix 17, B-1000 Brussels.

Fasina OO, Sokhansanj S (1996) Storage and handling characteristics of alfalfa pellets. Powder Handling and Processing 8(4): 361-365.

Holm JK, Henriksen UB, Hustad JE, Sorensen LH (2006) Toward an under-standing of controlling parameters in soft-wood and hardwood pellet production. Energy and Fuel 20: 2686-2694.

Karaca C (2019) Agricultural residues potential of Hatay. MKU. Tar. Bil. Derg. 24 (Special edition ) :9-15.

Mani S, Tabil LG, Sokhansanj S (2003) An overview of compaction of bio-mass grinds. Power Handling and Process 15: 160-168.

Nilsson D, Bernesson S, Hansson PA (2011) Pellet production from agricultural raw materials- a systems study. Biomass and Bioenergy 35: 679-689.

IKHKKY (2014) Regulations for Air Pollution Control Caused by Burning. http://www.mevzuat.gov.tr/, accessed on January 11, 2019.
Öztürk HH (2012) Energy plants and biofuel production. Hasad yayıncılık Ltd. Şti, İstanbul, pp: 272.

Theerarattananoon K, Xu F, Wilson J, Ballard R, Mckinney L, Staggenborg S, Vadlani P, Pei ZJ, Wang D (2011) Physical properties of pellets made from sorghum stalk, corn stoves, wheat straw and big bluesterm. Industrial Crops and Products 33(2): 325-332.

Tabil LG, Sokhansnj S (1996) Process conditions affecting the physical quality of alfalfa pellets. Applied Engineering in Agriculture 12(3): 345-350.

Tabil LG, Sokhansanj S (1997) Bulk properties of alfalfa grind in relation to its compaction characteristics. Applied Engineering in Agriculture, 13(4): 499-505.

Uysan O, Polatöz S (2020) Citrus production in the world and Turkey and froeign trade. https://www.turktob.org.tr/dergi/makaleler/dergi2 2/6-11.pdf, accessed on May 15,2020.

Werther J, Saenger M, Hartge EU, Ogada T, Siagi Z (2000) Combustion of agricultural residues. Progress in Energy and Combustion Science 26: 1-27. 